\title{
Intersections
}

Canadian Journal of Music

Revue canadienne de musique

\section{Barnardo Boys}

\section{Robin Elliott}

Volume 28, numéro 1, 2007

URI : https://id.erudit.org/iderudit/019293ar

DOI : https://doi.org/10.7202/019293ar

Aller au sommaire du numéro

\section{Éditeur(s)}

Canadian University Music Society / Société de musique des universités canadiennes

ISSN

1911-0146 (imprimé)

1918-512X (numérique)

Découvrir la revue

Citer cet article

Elliott, R. (2007). Barnardo Boys. Intersections, 28(1), 125-138.

https://doi.org/10.7202/019293ar

\section{Résumé de l'article}

La première de Barnardo Boys, sur une musique de Clifford Crawley, d'après un livret de David Helwig, a eu lieu à Kingston (Ontario) en mai 1982. Inspirés par la démarche de Benjamin Britten, les créateurs de cet opéra considèrent essentielles à la production de l'oeuvre l'implication dans la communauté et la coopération entre amateurs et professionnels. On ne trouvait dans la distribution qu'un chanteur professionnel provenant de l'extérieur : Jan Rubes, engagé pour jouer le rôle principal de Albert Ashby. Le livret et la musique de l'opéra font tous deux appels à un mélange de matériaux préexistants et nouveaux. Cette approche est considérée comme étant typique d'une préférence canadienne pour le genre de l'opéra documentaire, pendant musical de l'implication des romanciers canadiens dans l'écriture de fiction historique.
Tous droits réservés (C) Canadian University Music Society / Société de musique des universités canadiennes, 2007
Ce document est protégé par la loi sur le droit d'auteur. L'utilisation des services d'Érudit (y compris la reproduction) est assujettie à sa politique d'utilisation que vous pouvez consulter en ligne.

https://apropos.erudit.org/fr/usagers/politique-dutilisation/ 


\section{BARNARDO BOYS}

\section{Robin Elliott}

The publicity for and reception of a new Canadian opera typically concentrates on, in descending order, the opera company, the creative artists (composer, librettist, director), and the performers (professional singers). The sense of community involvement is minimal or non-existent; beyond buying a ticket to the production, the average citizen is not expected to contribute to or be involved in the production.

Twenty-five years ago a very different sort of operatic production saw the light of day in Kingston, Ontario. Barnardo Boy, with music by Clifford Crawley (b. 1929) and a libretto by David Helwig (b. 1938), set much of the received wisdom about operatic creation on its head. There was nothing radically different about the aesthetics and musical style of the opera itself; it was not an anti-opera or a work of experimental music theatre. But the production of Barnardo Boy was a community project from start to finish. The composer and the librettist were both local residents at the time, and with one notable exception, the opera was performed by local amateur or semi-professional musicians. It was not a show put on by imported professionals for the entertainment of an existing opera audience; rather it was local people telling a meaningful story through music and drama for their fellow citizens. For both audience and performers, there was a genuine sense of investment in and ownership of the work.

\section{Crawley, Helwig, and Barnardo}

Both Crawley and Helwig credit James Coles with originating the idea for what became Barnardo Boy in the late 1970s. ${ }^{1}$ Coles was the coordinator of the arts for the Frontenac County Board of Education at the time. ${ }^{2} \mathrm{He}$ had collaborated

1 David Helwig, email communication, 11 May 2007 (Helwig currently lives in Prince Edward Island); Clifford Crawley, interview at his home in St. John's, NL on 18 May 2007. The full score of Barnardo Boy, which includes a piano reduction by the composer of the orchestral parts, is available for rental from the Canadian Music Centre. Further materials pertaining to Barnardo Boy are in the David Helwig fonds at McMaster University, first accrual, group XIII Plays, box 29, files 8-15; an online finding aid is available at $<$ http://library.mcmaster.ca/archives/findaids/fonds/h/helwig.htm $>$ (accessed 16 May 2008). Crawley has documents relating to the opera in his personal possession, including the original and revised versions of the full score, publicity materials, and reviews; he kindly provided me with copies of these materials, for which I express my sincere thanks. James Coles also has documentary materials about Barnardo Boy in his possession, including a typescript of the complete libretto with stage directions, which he made available to me, for which I also record a debt of gratitude. I also thank all three men for sharing their recollections of Barnardo Boy with me-Helwig via email, and Crawley and Coles in person>.

2 In 1998, as part of the amalgamation policies and educational reforms of the Ontario provincial government under Mike Harris, the Frontenac County Board of Education merged with the Lennox \& 
with Crawley and Helwig in creating The Miracle Child to celebrate the United Nations Year of the Child (1979). Coles commissioned the poem from Helwig and the music from Crawley, and he had the resulting work performed by a massed choir and instrumental ensemble of the county schools. ${ }^{3}$ Coles subsequently developed an idea for a more ambitious project:

I started to think about something in the nature of the Benjamin Britten things with kids-something that would involve the Kingston Symphony Association and the school board. I think Cliff has a special gift for that kind of thing-he's an educator, he's a teacher. He knows about writing for kids and working with kids. ${ }^{4}$

Crawley was immediately enthusiastic about the idea. His own experience of Britten's dramatic works dated back to his time as a school teacher in England from 1952 to 1973:

I remember doing one of the first productions of Britten's Noye's Fludde after the Aldeburgh premiere when I was teaching in Devon. I had also done some school productions-I wrote a thing called The Rivers when I was in Plymouth as well. The idea of having people come from different directions and join in on a production seemed wonderful to me. Britten knew how to do that, on more than one occasion-his setting of Psalm 150, for instance. It was just right for me, and Jim Coles obviously felt the same way about getting adults and children all joining together. I think that's the ideal as far as I'm concerned. There's a place for professional opera companies-I don't mean that they are bad-but in a community the size of Kingston or St. John's, the idea of amateurs and professionals joining together feels like the right thing to do. ${ }^{5}$

Based on their experience with The Miracle Child, Coles and Crawley quickly decided to enlist Helwig to write the libretto. They faced stiff opposition at first. As Coles recalls it, "I spotted David at a concert and I approached him in person about the idea of writing an opera libretto that would involve children. He turned me down flat!"6 Helwig's recollection accords with this account:

One evening I went to a recital at the public library, a solo violin playing Bach, and Jim came up to me at intermission, grinning, and said he had a bright idea for me and Cliff.

"Not an opera," I said, presciently. "I don't much like opera."

But an opera was exactly what he had in mind. I said I'd think about it, not expecting much to happen.

\footnotetext{
Addington Board to create the Limestone District School Board; the position of arts co-ordinator was terminated soon thereafter when Coles retired.

3 The poem has been published (in Helwig 1982). The performances of Crawley's setting of the poem took place in hockey arenas in Kingston (Jock Harty Arena) and Godfrey (North Frontenac Arena); Helwig notes that "not a word was comprehensible" (email communication, as n. 1).

4 James Coles, interview at his home in Kingston, ON on 6 May 2007.

5 Crawley interview (as n. 1).

6 Coles interview (as n. 4).
} 
However.

The essential requirement was a large role for a choir of children, and not long after that conversation I suddenly thought of the Barnardo children. It was a subject that was in the air at the time, and more than one book came out-Kenneth Bagnell's, and another of oral history called The Home Children. I'd written an article about my old home town of Niagara-onthe-Lake not long before, and I'd seen the site of the home that had existed there.

So I began reading, and the basic structure, the old man, the girl, the flashbacks, came to me, and from then on it was easy sailing. ${ }^{7}$

Helwig, a prolific and versatile author, had already written in many literary genres, including novels, short fiction, poetry, plays, and essays. He had also written for radio, television, and newspapers. Notwithstanding his reservations about opera as a genre, he is also a fine amateur singer who had performed in many choirs and also as a bass soloist in works such as Handel's Messiah and the Mozart Requiem. ${ }^{8}$ Writing an operatic libretto was a new venture for him, but as he notes above, it seems not to have caused him undue difficulty. ${ }^{9}$

\section{The Barnardo Story}

Thomas John Barnardo was born in Dublin in 1845. As a medical student in London in the 1860s he became aware of the dire conditions of urban street children. In 1870 he set up the first Barnardo home for destitute children at 18 Stepney Causeway in London, and by the time of Barnardo's death in 1905 there were about 100 such homes throughout the United Kingdom. Barnardo children were housed, clothed, fed, and given a vocational training, but emigration was also an important part of the Barnardo system. The prime destination was Canada; over 30,000 Barnardo children were sent here between 1882 and 1939 (Corbett 1979, 127). After World War II, Barnardo children were no longer sent abroad; the last Barnardo office in Canada closed in 1960. The last traditional Barnardo home in England closed in 1989, but Barnardo's still flourishes as a charitable institution dedicated to helping out disadvantaged children. ${ }^{10}$

The decision to base the opera on the story of the Barnardo children struck a chord with Crawley, who had known Barnardo boys as schoolmates during his youth in England. As Helwig notes, there was a fair amount of interest in the

7 Helwig email (as n. 1). The books that Helwig mentions are Bagnell 1980 and Watson 1979. Coles (as n. 4) added that Helwig's choice of subject matter for the libretto was also influenced by a third book, Corbett 1979.

8 For more details on David Helwig's life and works, see Helwig 2006, and also his web site at <http://www.davidhelwig.com> (accessed 16 May 2008).

9 Helwig later wrote a second libretto for Crawley, The Pied Piper (1989), which is a play with music, intended for performance by a large cast of adults and children.

10 The Barnardo's web site (<http://www.barnardos.org.uk/>, accessed 16 May 2008) offers historical and current information about the organization, which is the largest children's charity in the UK. There is an extensive literature about Barnardo, both the man and the institution; for a recent critical and nuanced discussion of Barnardo history, see Koven 2004, especially chapter two, "Dr. Barnardo's Artistic Fictions: Photography, Sexuality, and the Ragged Child": 88-139. 
Barnardo story in the late 1970s and early 1980s, but many earlier works had portrayed and/or dramatized the story of the Barnardo children.

Pauline Johnson's short story “The Barnardo Boy," written in 1910, is a notable early Canadian fictional treatment of this subject matter. ${ }^{11}$ Johnson had experienced at first hand the horror and misery of the seedy side of London; she was deeply affected by what she saw, and sympathetic to the plight of the destitute people she encountered there. In her short story, Johnson makes Buckney, a Barnardo boy from the London slums, a heroic figure: he saves his adoptive Canadian family from death during a home invasion by two burglars. At the end of the story, Buckney confesses that he used to be ashamed of being a Barnardo boy. "You needn't be," replies a police officer. "It's not what a boy was, but what he $i s$, that counts nowadays. Good-night! I wish we had more Britishers like you." (Johnson 1913, 146) Johnson's portrayal runs counter to a good deal of antiBarnardo sentiment in Canada during the early years of the twentieth century. In Lucy Maud Montgomery's novel Anne of Green Gables, for instance, Matthew suggests to Marilla that they should get a Barnardo boy to help them out: "I said 'no' flat to that," Marilla informs Rachel Lynde. "They may be all right-I'm not saying they're not-but no London street Arabs for me." 12

The Barnardo story had been used for at least one previous work of musical theatre; it provided the subject matter for the first collaboration between Andrew Lloyd Webber and Tim Rice. Their musical The Likes of Us is set in Victorian London and tells the story of Dr. Barnardo. It was written in 1965, but Helwig and Crawley were not aware of it, as The Likes of Us did not reach the stage until a production was mounted at Lloyd Webber's Sydmonton Festival in 2005 to mark the work's fortieth anniversary. ${ }^{13}$

Although Helwig's Barnardo Boy is not explicitly set in Kingston, a local setting is implied, and the time is the present day (i.e. the 1980s). The title character is Albert Ashby, who is portrayed as an old man at the start of the opera. He is robbed and roughed up by a group of drunken teenagers on the street outside a school dance, but is comforted by a schoolgirl who escorts him back to his home and stays to hear him relate his life story in a series of flashbacks. (Albert as an old man is performed by a bass; in flashback scenes the child Albert is sung by a treble and Albert as a young man is sung by a baritone.) Albert lives alone and has never married. His mother died when he was two years old, and he and his older brother Will were forced to live on the London streets. The brothers are rescued by Dr. Barnardo and taken to Stepney. As Act One ends, an ailing Dr. Barnardo gives a speech at the Liverpool docks, where Albert and his brother are about to depart for Canada.

11 The story was first published in the periodical The Boys' World (13 August 1910); it later appeared in Johnson $(1913,139-46)$, and in this version it is now widely available online.

12 Montgomery (2004, 58). Anne of Green Gables was written in 1905 and first published in 1908. The term "street Arab" was used throughout the Victorian era to refer to urban homeless children, especially in London. Corbett $(1979,58-60)$ discusses the anti-Barnardo movement in Canada and states that for some people the term "Home Child," as used for Barnardo children, conferred "the connotation of second-class citizenship" $(1979,60)$.

13 For performance details, see <http://www.timrice.co.uk/likest.html> (accessed 16 May 2008). 
As Act Two opens, the brothers are separated upon arrival in Canada, and Albert is adopted by a brutal farmer. Sent to sleep in a cold barn, Albert fears he will die but is saved by a vision of his mother. He runs away, and is sent to a new family where he is treated somewhat better. He does well at school, and for a Christmas concert he recites the poem "Invictus" by William Ernest Henley. Both brothers serve in the Canadian armed forces during World War I; on the war front in Europe they have a chance brief meeting, but must part after exchanging a few words. Albert later learns that Will was killed a week after their meeting, and thus he has lost the only family he ever had. Albert returns to Canada after the war and works on the railroads until retiring on his meagre pension. As the opera closes, the girl leaves and Albert in his imagination is revisited by characters from his past. He recalls his recitation of "Invictus"-a modest achievement that was nevertheless the highlight of his life. ${ }^{14}$

\section{LibretTo AND CHARACTERIZATION}

The libretto is a skilful and effective piece of work. Numerous structural details give the opera a subtle but satisfying sense of unity. Albert is robbed by children as an old man, which leads him to recall being robbed as a child on the streets of London. Act One ends with Dr. Barnardo on the verge of death, and Act Two ends with Albert in the same condition. There is only one lead female rolethat of the unnamed girl who befriends Albert-a drawback from the point of view of conventional operatic casting. But there is a chorus of adults and one of children, which gave the opportunity for fifty local singers to get some stage experience and help to bring the work to life.

Albert is a fictional character, though he is based on the real stories of Barnardo children. The programme booklet for the premiere performance states that "Albert Ashby is not meant as a symbolic or representative figure. There were as many stories as there were Barnardo Boys. Albert's story is the story of one individual man, a man both ordinary and heroic." 15 Although Albert's story is fictional, it is embedded in a good deal of documentary material. The programme booklet for the first performance describes this aspect of the libretto:

The comments made by the philanthropists in the London scene are taken from Charles Booth's pioneering work of sociology, Life and Labour of the People of London. The story of Jim Jarvis, which Barnardo tells at Liverpool, is one that he used many times in pamphlets describing his work. Both

14 Crawley has noted certain parallels between his own life and that of Albert Ashby. Like the fictional Barnardo boy, Crawley's beginnings were rather humble; he was born in Dagenham, Essex, a town that was built around a Ford factory (Dudley Moore came from the same town). Crawley left school at 13 and, like Albert, he joined the army at 17 (fortunately World War II had ended the year before). And both Crawley and Albert Ashby left England to begin a new life in Canada. When I asked him if Albert is in any sense a self-portrait, however, Crawley laughed and noted one important difference: "I did have a mother and father who were really good to me" (Crawley interview, as n. 1). Jan Rubes, who created the role of Albert Ashby, also identified with the character; his biographer notes that "the words and feelings of the opera were very close to his own when he left his mother behind in 1948" (Schabas 2007, 193).

15 "Synopsis," Barnardo Boy programme, Grand Theatre-Kingston, May 12-15, 1982 [11] (collection of the author). 
words and music of the hymn in the Liverpool scene are those used on such occasions, and a brass band of Barnardo boys was always present. Barnardo died of a heart attack not long after seeing off a group of children. The words of the chorus in the World War I scene are taken from an actual set of field orders of the time and from a list of casualties in the official Canadian War History. ${ }^{16}$

Of the quoted textual materials, the most striking is "Invictus," recited near the beginning of Act Two, and again at the end of the opera. Henley's poem has given the world two classic expressions: "bloody but unbowed" and "I am the master of my fate, I am the captain of my soul". The poem was written in 1875, just after Henley had lost part of a leg when it was amputated due to tuberculosis of the bone. Henley (1849-1903) was an almost exact contemporary of Dr. Barnardo (1845-1905), and his "Invictus," like Rudyard Kipling's "If” (1895), is a classic expression of the Victorian era's belief in stoicism in the face of adversity-a character trait that was no doubt instilled in all of his young charges by Dr. Barnardo.

\section{BARNARDO BOY AS DOCUMENTARY}

Although Helwig may not have been aware of it, the documentary character of Barnardo Boy is shared with many other Canadian operas. Just as Canadian filmmakers have made important contributions to documentary film, so too Canadian librettists and composers have especially cultivated the genre of documentary opera. The libretti of James Reaney are noteworthy in this regard, including Serinette (with music by Harry Somers, 1989-90) and Taptoo! (with music by John Beckwith, 1993-5). ${ }^{17}$ Some other notable documentary operas on Canadian subjects include Louis Riel (libretto by Mavor Moore and Jacques Languirand, music by Somers, 1967), La Tourangelle (libretto and music by Istvan Anhalt, 1975), The Last Duel (libretto by Michael Patrick Albano, music by Gary Kulesha, 1999), The Iron Road (libretto by Mark Brownell, music by Chan Ka Nin, 2001), Filumena (libretto by John Murrell, music by John Estacio, 2003), Ann and Séamus (libretto and music by Stephen Hatfield, 2006), Frobisher (Murrell/Estacio, 2007), and Trudeau: Long March, Shining Path (libretto by George Elliott Clarke, music by D.D. Jackson, 2007).

Perhaps this predilection for documentary opera arises from our deep-seated suspicion of frivolity: Canadians seem to feel that opera, or at least new operatic works, should be didactic in nature, rather than simply provide us with entertainment. David Prosser in a review of Barnardo Boy outlined another reason why Canadian authors and composers may be drawn to the genre of documentary opera:

16 Ibid. Various editions of Booth's Life and Labour of the People in London, which eventually reached 17 volumes, were published between 1889 and 1902. The hymn in the Liverpool scene is "God be with you till we meet again," words by Jeremiah Rankin (1882) and music by William Tomer (1880).

17 Both of these libretti are published in Reaney 2004. On the documentary content of Taptoo! see Elliott 2003. 
History isn't enough to make a past. History has to be transmuted into art as well-heightened, dramatized, even falsified, if need be-before it can enter our consciousness and give us a sense of who we were and who we are. And whatever its merits as an operatic or dramatic work, Barnardo Boy is of value as transmuted history. The fact that its subject has been thought worthy of turning into art helps to ensure that that subject will not be wholly forgotten (Prosser 1982).

Barnardo Boy can thus be seen as part of a larger project for new operatic creation in Canada: these works inform us as well as entertain us, and they tell us who we are and where we have come from.

In considering the comparable upsurge of interest among Canadian novelists for historical fiction in the late-twentieth century, Margaret Atwood observed that there were a number of factors that led to this phenomenon (Atwood 1998). ${ }^{18}$ One was an increase in national self-confidence: we are now allowed to find ourselves interesting. A second reason was that Canadians were retreating to the past to flee from our troubled and troubling present. A third idea that Atwood presents is that sheer curiosity led writers to examine our past-the thrill of time travel, and the desire to know how people lived their lives back then and understand whether what they did lives on in us. Finally, Atwood regards the turn to historical fiction as a stage in our maturation process as a nation. As she puts it, "Nothing is more boring to a fifteen-year-old than Aunt Agatha's ramblings about the family tree, but often, nothing is more intriguing to a fiftyyear-old. It's not the individual authors who are now fifty-some of them are a good deal younger than that. I think it's the culture" (Atwood 1998, 1511). ${ }^{19}$ Atwood's observations are certainly pertinent to Barnardo Boy, and they help to explain the opera's relevance both to its own day and age, and to ours.

\section{Musical Style}

The wide-ranging times and locations of the libretto of Barnardo Boy-from Victorian London to a Canadian farm to the trenches of World War I, and on to Kingston in the 1980s - are matched by a similar diversity of musical styles. The opera opens with a pre-recorded rock group performing a popular song that serves multiple functions - it is both the diegetic music for a dance that is taking place in the school auditorium, and a musical portrayal of the rowdy boys on the street who have been expelled from the dance for underage drinking. The song immediately casts the elderly Albert Ashby in the role of an outsider (the music is clearly not his), and both the lyrics ("I'll never find a place to park / I can't understand the rules of the game") and the music of the song introduce one of the central themes of the opera-alienation. The disorderly boys on the street have been cast out from the polite society of the school dance, and thus are alienated from their peers. As a Barnardo boy, Albert Ashby has experi-

18 Atwood's essay was originally delivered as the Bronfman Lecture in Ottawa in November 1996 and was also published separately by the University of Ottawa Press in 1997. The summary of Atwood's ideas presented in this paragraph is taken from pp. 1510-12.

19 Crawley was 52 when he wrote Barnardo Boy, and Helwig was 43. 
enced alienation all his life, but as a single, lonely, elderly man, his isolation has reached a new peak of intensity.

One thing that the popular music is not intended to do is draw any sort of a class distinction in the opera. Crawley's experience of popular music reached back to his youth in England, and his views about it are decidedly egalitarian:

In my early days I played pop music; it was one of the things that kept me sane, I suppose. We played dances and so on. It has nothing to do with today's pop music, but it was that day's pop music. My parents and family weren't musicians and didn't listen to classical music; popular music was their thing. I don't feel this class distinction-I don't feel that one is of a lower class than the other. Not many people can do both-I know I can't do pop music today-it's a whole world that I'm not very enamoured of, but it's not a question of hierarchy. If you are a composer like I am, you should be able to handle a bit of pop music. It might not be very good, but you should have the technique to at least be able to imitate it. I admire Leonard Bernstein for that reason. ${ }^{20}$

The first dramatic style shift in the opera occurs as the rock group fades out and the orchestra enters. The last phrase of the rock song is repeated and woven into some complex imitative polyphony in the woodwinds and strings, matched by a concomitant increase in harmonic dissonance. This introduces Crawley's own personal modernist musical language-tonally based, but with non-traditional chord structures, whole tone scales, melodic and harmonic chromaticism, and other similar traits that are hallmarks of his distinctive and personal late-twentieth-century idiom. ${ }^{21}$

Changes of musical style are handled with great subtlety throughout the opera. Crawley has a sure feel for how to use dissonance and textural complexity when the action of the libretto warrants it (e.g. when Albert is attacked by the young ruffians, when the terrified Barnardo children are waiting to be matched up with their adoptive families in Canada, and at the climax of the scene set on the front lines of a World War I battle) but he also knows how to employ common practice tonality and simpler textures when this suits the dramatic situation (e.g. when the girl comforts Albert and walks him to his home, or for the scenes when Albert thinks with great fondness about his mother).

The documentary materials that appear in the libretto are paralleled by quoted musical materials in the opera. Intertextual musical references include both stylistic allusions and directly quoted materials. In a scene set in the London slums, a group of philanthropists sing "In modo di 'Anglican Chant"' (Crawley

20 Crawley interview (as n. 1). In the $20^{\text {th }}$-century compositional techniques course that I took with Crawley at Queen's University in the 1976-77 academic year, one of our assignments was to write a pop song. He informed us that it was just as hard to write a good pop song as it was to do any of the other pastiche assignments for that course, which ranged from Debussy to Messiaen and Cage. I proved the truth of his assertion by writing an appallingly bad pop song for my assignment.

21 A thorough discussion of Crawley's style as a composer, together with a detailed biographical study, is available in Beverley Diamond's forthcoming article on Crawley (see Reference list). 
1981, 60); perhaps Crawley is gently satirizing their social gospel inclinations. ${ }^{22}$ A variety of old London street cries are also quoted in this scene. Whenever Dr. Barnardo appears on stage, march rhythms usually predominate, reflecting the military nature of his bearing and of his organization. As noted above, in the Liverpool scene the hymn "God be with you till we meet again" is used; Crawley quotes Tomer's music for the hymn and scores it in Salvation Army style, for brass band and bass drum. In the World War I scene, brass players perform military fanfares and popular songs of the era; these serve as the musical accompaniment for the quoted documentary textual materials in this scene which are not sung, but rather are set as a rhythmic speech chorus. ${ }^{23}$ "Invictus" is also recited rather than sung both times it appears; the poem is set as a melodrama, with the text freely declaimed over softly moving chords in the strings and woodwinds. ${ }^{24}$ The first time the poem appears (Crawley 1981, 228-31), it is recited by the singer who performs the role of Albert in his old age; it reappears at the very end of the opera (Crawley 1981, 302-03), performed with moving effect by the boy who portrays young Albert in the flashback scenes. The most complex textures in the opera appear just before this second recitation of "Invictus." At this point, the characters from Albert's past reappear, along with the music that was associated with them. It is a wonderfully moving evocation of the idea that one's life passes before one's eyes-or in this case, one's ears-at the point of death. ${ }^{25}$

One of the significant challenges for Crawley was to create a work that could be done by a cast of amateur singers; the role of Albert Ashby is the only one that requires an accomplished professional performer. When Crawley composed the opera, none of the roles had been cast, and Crawley wrote the part of Albert for a high bass. The casting of this role was seen as crucial to the success of the opera; as Coles recalls it, Helwig said "We need a star. We're not going to be able to make this thing fly unless we've got a name." 26 In the end, Jan Rubes was hired to star as Albert, and Helwig feels that Rubes did indeed carry the show: "He was the essential element of the production, since he had the experience and force of character to be on stage throughout and hold the show together." 27 Rubes, however, is a low bass and he found much of the role of Albert to be

22 As noted above, the words in this scene are taken from the work of Charles Booth. Booth was raised in the Unitarian church, but in practice the social gospel movement that he and Potter represent also included many Anglicans, as well as Wesleyans, Quakers, and other Christian denominations. A good many atheists, agnostics, communists and adherents of a host of other non-religious belief systems were also campaigning on behalf of the disadvantaged in the Victorian era and beyond, but they would not likely have identified themselves as part of the social gospel movement.

23 See Anhalt $(1984,13-15)$ for a discussion of the rise and spread of the speech chorus in Europe during the period just before and after World War I.

24 The poem has not often been set to music, though there is a fairly well known setting for baritone and piano by Bruno Huhn (Boston: Arthur P. Schmidt, 1910) which has been recorded several times.

25 Henley's "Invictus," then, is the last thing that passes through Albert Ashby's mind before he dies. In a coincidental case of reality mirroring fiction, on 11 June 2001 Timothy McVeigh wrote the poem out by hand as his final statement before being executed for his role in the 1995 Oklahoma City bombings.

26 Coles interview (as n. 4).

27 Helwig email (as n. 1). 
uncomfortably high in tessitura-and so Crawley had to transpose and rescore many of the sections in which Albert sings. In retrospect, Crawley is philosophical about what this entailed:

It was a lot of extra work to rewrite it [the role of Albert] and to make the joins come together again. The orchestration had to be lightened. But it was worth it because he [Rubes] was really good in the part, and I think he inspired the rest of the cast. ${ }^{28}$

Over forty pages of the 305-page full score had to be substantially rewritten, and other pages required lesser changes as well. ${ }^{29}$ It is characteristic of Crawley's professional attitude and unflappable nature that he did not complain about being required to do this.

\section{BARNARDO BOY ON STAGE}

As noted at the outset, the production of Barnardo Boy in 1982 in Kingston was a community effort. Local groups which participated in or helped with the work included the Frontenac County Board of Education, the Kingston Symphony and Kingston Youth Orchestra, the Grand Theatre (where the work was staged), Theatre 5 (a local dramatic society), and the local radio station CFLY-FM. There were fifty-six local performers on stage, twenty-two musicians in the pit, and about forty people who had helped out behind the scenes with building and painting the sets, sewing the costumes, doing the make-up, securing props, and attending to the direction, the stage and costume design,,$^{30}$ and the lighting and sound for the production. Whole families got involved. Helwig not only wrote the libretto, he also helped to build the sets and sang the role of Dr. Barnardo. His wife at the time, Nancy Helwig, was the manager of the Grand Theatre and co-produced the show, was responsible for the publicity, and helped to paint the sets. James Coles conducted the opera, his wife Beverley Coles helped to paint the sets and sang in the adult chorus, and his daughter Janice Coles sang the role of the girl who befriends Albert.

The production was not without its tensions. As Coles recalls, "If you think you can do something like this without any problems, then you're really kidding yourself; you shouldn't be starting it at all." 31 One of these tensions involved Coles himself and his relationship to Rubes.

Certainly Jan right from the beginning was the star in every sense: he knew how it should be conducted and he knew how it should be directed. I recall feeling very upset after the first rehearsal with orchestra at both direct and

28 Crawley interview (as n. 1).

29 In most of the sections where, in the original version, the singer is required to reach middle C or higher, Crawley transposed the vocal part lower (the interval of transposition ranged from a major second to a perfect fourth); this, of course, entailed transposing the orchestral parts as well-and also changing the orchestration if the transposition took the music out of the range of the original instrument (e.g. some second violin lines had to be moved into the violas).

30 Reg Bronskill, a professional stage designer and Kingston native, provided the very effective sets for the opera.

31 Coles interview (as n. 4). 
indirect criticism that was being levelled my way. But I told myself, you know, "Damned if I'm gonna let this big-name star push me around," and in the course of things, it worked out fine. ${ }^{32}$

A second area of tension concerned the publicity for the production. Nancy Helwig, in her role as the publicist, decided that they would not be able to sell enough tickets for the four performances of the work if they advertised it as an opera. As a result, the advance publicity in the local newspaper called the work a musical rather than an opera. In some of the publicity, Jan Rubes's name appeared in large font, but there was no mention of either the composer or the librettist. In publicity flyers that circulated locally to advertise the production, the names of Crawley and Helwig did appear, but in much smaller font size than that of Rubes's name. In a letter to the editor of the local newspaper, Crawley's colleague F.R.C. Clarke, head of the department of music at Queen's University at the time, noted this lack of recognition for Crawley:

[In] the publicity for Barnardo Boy . . . the composer of the music (Mr. Crawley) rarely seemed to get any attention. However, in the perspective of history, operas tend to be primarily remembered and associated with their composers, so time will probably right the initial imbalance (Clarke 1982). ${ }^{33}$

Two reviews of Barnardo Boy appeared in the local newspaper, and each one also set the matter straight about the genre of the work.

The poster, you may have noticed, refers to it as a "musical," perhaps on the theory of not wanting to scare away potential audience members who might cringe at the term opera. But it is opera, in the best sense of that word, and without many of the failings and excesses for which bad opera has become famous (Barber 1982).

An opera from Kingston: there's something impressive about the sound of that. Fearful of the taint of elitism and conscious of Kingston audiences' taste for light-hearted spectacle, the theatre has been billing the show as a "musical." But it is more than that. We have had new musicals here before; this is different. Let's admit it: this is full-blooded opera (Prosser 1982).

The review in Opera Canada simply called the work an opera and did not even mention that it had ever been billed as a musical (Mercer 1982).

There was something decidedly Canadian about the ambivalence surrounding the publicity for Barnardo Boy. The perception was that there would be no audience for a new opera, as this is an elitist art form-but at the same time there was a gala opening night performance with "V.I.P. Seats" for \$25 (regular ticket prices ran from $\$ 6$ to $\$ 10$ ), an example of elitism in its most transparent

32 Coles interview (as n. 4). In response to an earlier draft of this article, Helwig (in an email on 5 October 2007) asserted that in no sense was Rubes a star throwing his weight around-on the contrary, Rubes was extremely helpful and considerate to all involved in the show and his contributions did much to improve the quality of every aspect of the production.

33 Clarke's letter was written in response to an earlier letter to the editor by E.F. Schrey (published 21 May 1982) that was highly critical of Barnardo Boy. 
form. ${ }^{34}$ Community involvement was a selling point in the publicity ("a local cast of $56 \ldots$ the world premiere of a work written by a Kingston composer and a Kingston author" ${ }^{35}$ ) but was trumped by Jan Rubes as the primary focus of the ads. Rubes was known to Kingstonians not primarily as a star of the Canadian Opera Company, but rather for his movie roles; his most recent film, a spy thriller called The Amateur, had played in local cinemas just six weeks before Barnardo Boy opened. ${ }^{36}$ An article in the local newspaper the day after the premiere of Barnardo Boy dwelt at some length upon Rubes's prowess as a tennis player (Bernard 1982). Perhaps it was felt that Kingstonians needed to be reassured that, despite the fact that Rubes was a professional opera singer, his virility was not in question. And this in turn was no doubt meant to let Kingstonians know that it was safe to buy a ticket for Barnardo Boy-the opera that was disguised as a musical.

Barnardo Boy came to mean something different to everyone who experienced it. Due to the involvement of the Frontenac County Board of Education, a special matinee performance was put on for an audience of school children. It was a daunting prospect-a large crowd of restless schoolchildren being forced to sit through a ninety-minute long opera in a modernist idiom on a rather sombre subject. But for David Helwig, this was perhaps the most memorable outcome of the production: "I still feel quite proud of that show. That we held the attention of 800 kids at a matinee with an original opera always felt like an achievement."37

F.R.C. Clarke noted another highlight of the show: "My impressions are that most of the audience found Barnardo Boy a moving experience, particularly the surprising number who were themselves related to-or descended fromBarnardo children" (Clarke 1982). ${ }^{38}$ For Crawley, this was a highlight of his involvement with the production:

Several people contacted us and said that they were Barnardo boys and that they hadn't told many people about this because it was something that they had been a little ashamed of-that you were an orphan, that nobody wanted you. It was lovely that they came out of the woodwork and suddenly felt this recognition here-"I haven't got anything to be ashamed of-this is a story I might tell people, and people might be fascinated by it." That was probably one of the most rewarding things about writing this piece. ${ }^{39}$

34 Prosser 1982 gently and amusingly skewered the pretensions of the opening night gala performance, and noted that only about 40 tickets were sold at the VIP price. Helwig (as n. 35) writes that "however she did it, Nancy sold the place out for a number of performances, which no one else could have done. As to the VIP tickets, 40 of them would have added 600 dollars to the kitty, and since we had a big band at union rates plus all the other expenses, every penny counted. The show did a little better than breaking even, and Cliff and I got a few dollars."

35 Barnardo Boy publicity flyer, collection of the author.

36 See Schabas $(2007,190-91)$ for further details about the film The Amateur and Rubes's role in it.

37 Helwig email (as n. 1).

38 It was through attending Barnardo Boy that I learned a piece of my own family history: the caregiver who had helped to raise my older siblings and myself had been a Barnardo child.

39 Crawley interview (as n. 1). 
If Barnardo Boy were to be mounted again today, it is not likely that many Barnardo boys would come forward. No Barnardo children emigrated to Canada after 1939, so the youngest of them would be in their late seventies now. Barnardo Boy has moved on from being a documentary opera about the present day to become an historical opera about the past-a product of its own particular time and place. But it is none the weaker for that. And while Crawley is not optimistic about the chances of a revival-"I can't imagine it getting performed again," he does not rule out the chance that its fortunes may turn around- "but one never knows: unusual, unexpected things happen sometimes." ${ }^{40}$

\section{REFERENCE LIST}

Anhalt, Istvan. 1984. Alternative Voices: Essays on Contemporary Vocal and Choral Composition. Toronto: University of Toronto Press.

Atwood, Margaret. 1998. "In Search of Alias Grace: On Writing Canadian Historical Fiction." The American Historical Review 103/5: 1503-16.

Bagnell, Kenneth. 1980. The Little Immigrants: The Orphans Who Came to Canada. Toronto: Macmillan.

Barber, David. 1982. "Barnardo Boy: A Masterful Achievement to be Proud Of." Kingston Whig Standard. 13 May.

Bernard, Laurel. 1982. "On the Stage, On the Tennis Court, Jan Rubes Moves Like a Youngster." Kingston Whig Standard. 13 May.

Booth, Charles. 1892-1902. Life and Labour of the People in London, 17 vols. London: Macmillan.

Clarke, F.R.C. 1982. "One Letter Notwithstanding, Barnardo Boy Was a Coup." Letter to the Editor. Kingston Whig Standard. ca. 22 May.

Corbett, Gail H. 1979. Barnardo Children in Canada. Peterborough: Woodland.

Crawley, Clifford. 1981. Barnardo Boy, opera to a libretto by David Helwig. Unpublished score, available from the Canadian Music Centre.

Diamond, Beverley. Forthcoming. "Conversations with Clifford Crawley." Musical Traditions, Cultures and Contexts: Festschrift for Beverley Diamond, edited by Gordon E. Smith and Robin Elliott. Waterloo: Wilfrid Laurier University Press.

Elliott, Robin. 2003. "Sounds Canadian: Music, History, and Music History in Taptoo!" Online at <https://tspace.library.utoronto.ca/bitstream/1807/755/3>.

Helwig, David. 1982. The Rain Falls Like Rain. Ottawa: Oberon.

- 2006. The Names of Things. Erin: Porcupine's Quill.

Johnson, Pauline. 1913. The Shagganappi. Toronto: William Briggs.

Koven, Seth. 2004. Slumming: Sexual and Social Politics in Victorian London.

Princeton, NJ: Princeton University Press.

Mercer, Ruby. 1982. "Kingston Opera." Opera Canada 23/3: 24.

Montgomery, Lucy Maud. 2004. Anne of Green Gables, edited by Cecily Devereux. Peterborough: Broadview.

40 Crawley interview (as n. 1). 
Prosser, David. 1982. "The Grand's Gala Night: Red Carpets and Commissionaires." Kingston Whig Standard. 13 May.

Reaney, James. 2004. Scripts: Librettos for Operas and Other Musical Works. Toronto: Coach House Books.

Schabas, Ezra. 2007. Jan Rubes: A Man of Many Talents. Toronto: Dundurn.

Watson, Phyllis, ed. 1979. The Home Children: Their Personal Stories. Winnipeg:

Watson \& Dwyer.

\begin{abstract}
The opera Barnardo Boys, with music by Clifford Crawley and libretto by David Helwig, was premiered in Kingston, Ontario in May 1982. Inspired by the example of Benjamin Britten, the creators of the opera regarded community involvement and cooperation between amateurs and professionals as essential to the production of the work. There was only one imported professional singer in the cast-Jan Rubes, who was hired to play the lead role of Albert Ashby. Both the libretto and the music of the opera make use of a combination of pre-existing and newly created source materials. This approach is seen to be typical of a Canadian preference for the genre of documentary opera, which parallels an engagement with historical fiction on the part of Canadian novelists.
\end{abstract}

\title{
RÉSUMÉ
}

La première de Barnardo Boys, sur une musique de Clifford Crawley, d'après un livret de David Helwig, a eu lieu à Kingston (Ontario) en mai 1982. Inspirés par la démarche de Benjamin Britten, les créateurs de cet opéra considèrent essentielles à la production de l’ouvre l'implication dans la communauté et la coopération entre amateurs et professionnels. On ne trouvait dans la distribution qu'un chanteur professionnel provenant de l'extérieur : Jan Rubes, engagé pour jouer le rôle principal de Albert Ashby. Le livret et la musique de lopéra font tous deux appels à un mélange de matériaux préexistants et nouveaux. Cette approche est considérée comme étant typique d'une préférence canadienne pour le genre de l'opéra documentaire, pendant musical de l'implication des romanciers canadiens dans lécriture de fiction historique. 